\title{
Analysis of Causes and Effects on Social and Economic Conditions in Southeastern Coastal Belt of Sri Lanka.
}

(Special Reference to Proposed Project on Mining of Heavy Mineral Sands along the Akkaraipattu - Komari Coastal Stretch)

\author{
S.H.A. Ashraff \\ Environmental Specialist, iRoad Project, RDA, Ministry of High Ways, Sri Lanka, \\ DOI: $10.31364 / \mathrm{SCIRJ} / \mathrm{V} 9.106 .2021 . P 0621866$ \\ http://dx.doi.org/10.31364/SCIRJ/v9.i06.2021.P0621866
}

\begin{abstract}
The study area has a coastline of $48 \mathrm{~km}$, with abundant natural resources supporting many livelihoods. Lagoons, rivers, bays, dunes, mangroves, estuaries, rocky shores, salt marshes, tidal flats, beaches, spits, estuaries, coral reefs and seagrasses are important habitats found along its coastline. The long coastline in the study area is one among the spots where active deposition is taken place. Because of its abundant natural resources and consequent social and economic benefits, the Sri Lankan coastal zone has experienced immense development and urbanization over the decades. Approximately 11.3 million people live in coastal districts while $61.6 \%$ of all industries operate in the coastal region. This calls for sustainable management of the coastal zone to ensure resources are not exploited beyond regeneration and habitats are not degraded or destroyed. Since the end of three decades of old civil war which increased the vulnerability of the people to the 2004-Tsunami natural disaster, this study area has been in daring need of inclusive development activities with a wide range of participation of multi-stakeholders including civil societies, to move towards growth while recovering from the devastation.
\end{abstract}

Keywords: Socio-economic profile, Community assets.

\section{INTRODUCTION:}

The study area, the Ampara district, covers a part of the eastern province of Sri Lanka. It ranges from the northern latitude $60^{\circ}$ $55^{\prime}$ to $81^{0} 50^{\prime}$ geologically. it's situated in the dry zone of the country and it receives an annual rainfall of $1400 \mathrm{~mm}$ mainly during the North-East monsoon season. But the rainfall gets low during the southwest monsoon and inter-monsoon period. The mean air temperature is $25^{\circ} \mathrm{C}$, atmospheric depression is between 1005 and $1013 \mathrm{mb}$ and the wind speed is $6-16 \mathrm{~km}$ per minute and it gets sunlight for 5 to 9 hours. The mean temperature is $30^{\circ} \mathrm{C}$. The highest temperature is $36^{\circ} \mathrm{C}$. The lowest temperature is $24^{\circ} \mathrm{C}$ during December and January periods. The district experiences a dry season from March to September and a rainy season from October to February.

The topography of the study area is located in the coastal plain of the island. The land is also completely flat; rising imperceptibly from sea level to approximately 100 feet in the west, the highest point, rising to 250 feet above sea level on the southwest corner of the study area.

Generally, the soils are gravelly clay loams with a sandy clay loam surface horizon. They are moderately deep, well-drained and reddish-brown. This area is consisting fertile soil. Those are generally medium to fine texture are dark in colour. The northeast section is low-lying, and the soils are dark grey sandy clay loams. The drain is very poor, and the land becomes over logged during the rainy season. Four different lagoons were considered for the study. According to table 1.01, they are Komari, Periya Kalapu, Korai, and Thimbutu Lagoons. They come under Allayadivembu, Addalachenai, Pottuvil and Thirrukovil divisional secretarial zones along the coastal belt of Ampara district

Table - 1.01: Lagoons in the Study Areas.

\begin{tabular}{|c|c|c|c|c|c|c|c|}
\hline 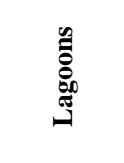 & 国 & 啻 & 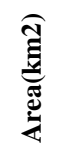 & 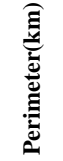 & 疋 & $\underset{\dot{d}}{\stackrel{0}{*}}$ & 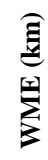 \\
\hline $\begin{array}{l}\text { Periya } \\
\text { Kalapu }\end{array}$ & $\begin{array}{l}7^{\circ} 09^{\prime} \\
\mathbf{4 5 . 4 2 "} \\
\end{array}$ & $\begin{array}{l}81^{\circ} 50^{\prime} \\
29.97^{\prime \prime}\end{array}$ & 18.37 & 33.67 & 6.96 & DL2 & 0.22 \\
\hline $\begin{array}{c}\text { Korai } \\
\text { Complex }\end{array}$ & $\begin{array}{l}7^{\circ} 03^{\prime} \\
13.81^{\prime \prime}\end{array}$ & $\begin{array}{l}81^{\circ} 51^{\prime} \\
17.27^{\prime \prime}\end{array}$ & 38.44 & 138.15 & 10.75 & DL2 & 0.12 \\
\hline Thimbutu & $\begin{array}{c}7^{\circ} 00^{\prime} \\
58.78^{\prime \prime} \\
\end{array}$ & $\begin{array}{l}8^{\circ} \mathbf{5 2}^{\prime} \\
31.36^{\prime \prime} \\
\end{array}$ & 1.23 & 15.67 & 12.52 & DL2 & - \\
\hline Komari & $\begin{array}{l}6^{\circ} 59^{\prime} \\
01.90^{\prime \prime} \\
\end{array}$ & $\begin{array}{l}81^{\circ} 51^{\prime} \\
18.74^{\prime \prime}\end{array}$ & 4.68 & 13.37 & 5.48 & DL2 & 0.11 \\
\hline
\end{tabular}

Source: EIA report for a Mineral Mining Project 2019.

\section{METHODOLOGY}

Location of the study area: The study areas are located in

1 Mining of Heavy Mineral Sands along with the Akkaraipattu - Komari Coastal Stretch (Oluvil Mineral Sands Project) and ${ }^{2}$ Establishment of Mineral Sand Processing Plant at the Oluvil Port Premises in Ampara District in Eastern Province. Ampara District Secretariat where the study areas are located is listed in Table 2.01 below.

Table 2.01: Grama Niladhari Divisions, Local Authority's, Divisional Secretariat Divisions within the Study Area.

\begin{tabular}{|c|c|c|c|}
\hline Study Areas & 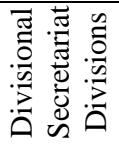 & $\begin{array}{l}\text { Grama Niladhari } \\
\text { Divisions (GND) }\end{array}$ & 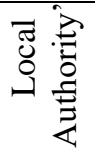 \\
\hline & 止 & $\begin{array}{l}\text { Vinayagapuram } \\
\text { (TK10A/2)03 }\end{array}$ & 司 \\
\hline
\end{tabular}




\begin{tabular}{|c|c|c|}
\hline $\begin{array}{c}\text { Mining of Heavy } \\
\text { Mineral Sands along }\end{array}$ & & $\begin{array}{c}\text { Sangamam Kiramam } \\
\text { (TK 10D) }\end{array}$ \\
\hline $\begin{array}{c}\text { the Akkaraipattu } \\
\text { - Komari Coastal } \\
\text { Stretch }\end{array}$ & & Thandiyadi (TK 10C) \\
\hline \multirow{2}{*}{$\begin{array}{c}\text { Mineral Sand Processin } \\
\text { Plant at the Oluvil } \\
\text { Port Premises. }\end{array}$} & \multirow{2}{*}{$\begin{array}{l}\text { Addala } \\
\text { chenai }\end{array}$} & Oluvil \\
\hline & & Palamunai \\
\hline
\end{tabular}
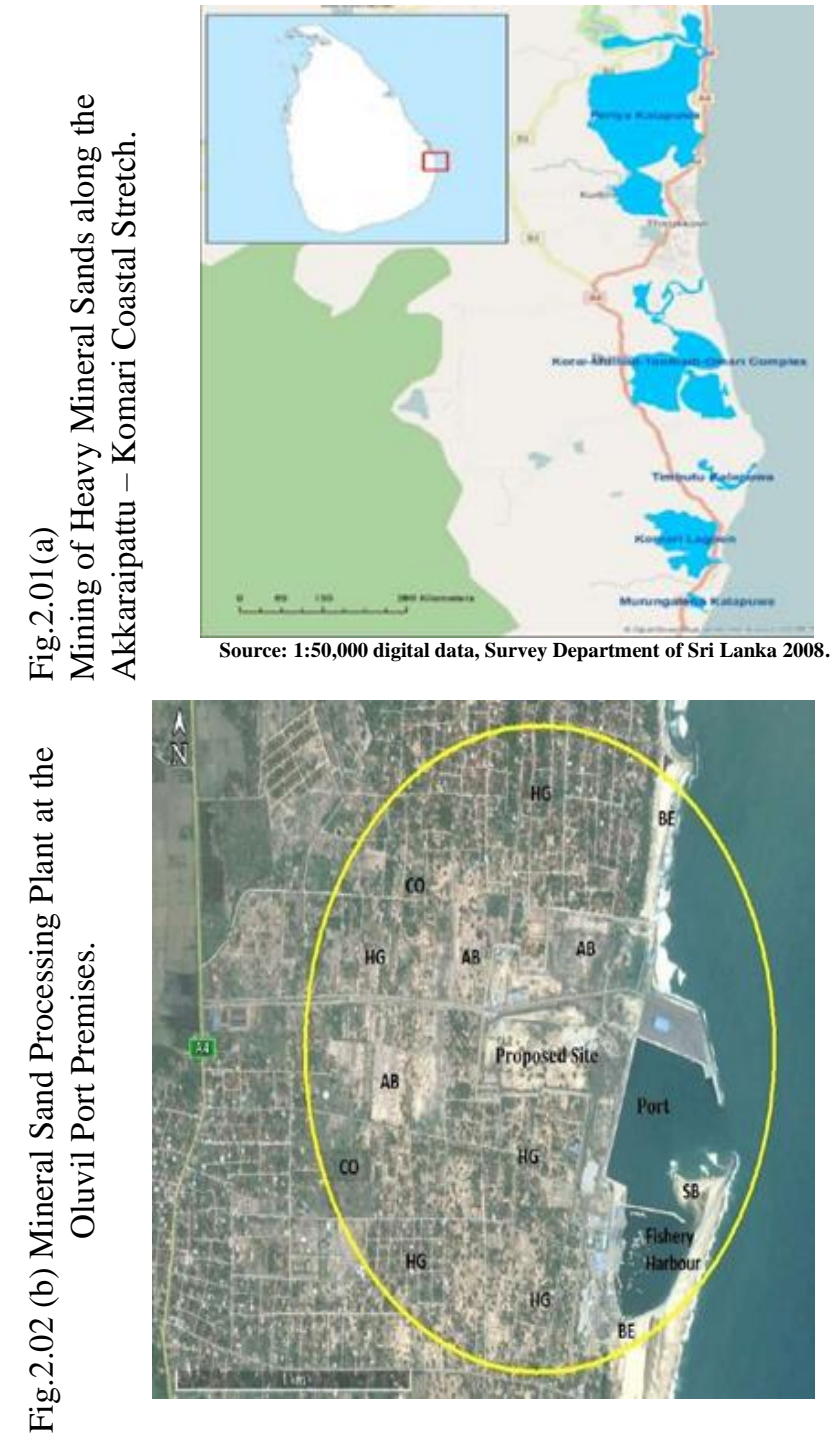

Figure 2.01, (a) Mining of Heavy Mineral Sands along the Akkaraipattu - Komari Coastal Stretch and Figure 2.02(b) Mineral Sand Processing Plant at the Oluvil Port Premises show the geographical outline for the study area. In the collection of necessary information and data for the study, the researcher depended on both qualitative and quantitative data from both primary and secondary sources. Informal direct interviews were conducted incorporating both men and women from different sets of people throughout the research process. The direct interview methods were used to gather primary information. The criteria for the selection of individual and group interviewees have been based on the recommendations of government officials and non-government officials.

A hundred samples have been collected by Questionnaire survey. These 100 samples were distributed to different stakeholders as follows; Development Officers-10, Fisheries Officers -6 , Fishermen -30, vegetation cultivator-06, Tourism related business group-08, religious leaders-10, Rural development society key members-10, Public-20. Field observation has been done in the study area. Direct interview; questions were prepared and discussed with individuals and group of people based on the study focus.

Both the primary and the secondary data have been used to fulfil the objectives of the study. Randomly selected 100 residents around the beach area were subjected to collect primary data through a questionnaire survey, focus groups discussion and field direct observation. A hundred residents responded to the questionnaire which mainly focused on the assessment of the mining of heavy mineral sands project against Causes and Effects of community assets, and livelihood activities in the study area.

Table 2.02. Number of households surveyed in the selected villages.

\begin{tabular}{|c|c|c|c|c|c|c|}
\hline Study Area & 节 & 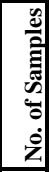 & $\stackrel{\frac{0}{\pi}}{\sum^{\pi}}$ & 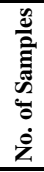 & हूँ & 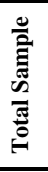 \\
\hline Sinnamuhathuaram & 120 & 2 & 104 & 3 & 244 & 5 \\
\hline Thambaddal $01 \& 02$ & 570 & 2 & 532 & 3 & 1102 & 4 \\
\hline $\begin{array}{l}\text { Thambiluvil } 01 \text { West \& } 01 \\
\text { East }\end{array}$ & 2005 & 6 & 1968 & 10 & 3973 & 16 \\
\hline $\begin{array}{l}\text { Thambiluvil } 02 \text { North,02 } \\
\text { East \& } 02 \text { West }\end{array}$ & 2018 & 6 & 1974 & 10 & 3992 & 16 \\
\hline Thirikkovil 03 \& 01 & 1465 & 4 & 1273 & 6 & 2738 & 11 \\
\hline $\begin{array}{l}\text { Vinayagapuram } \\
2,3 \& 4\end{array}$ & 2936 & 9 & 2602 & 13 & 5538 & 22 \\
\hline $\begin{array}{l}\text { Sangamamgram, Thandiyadi } \\
\& \text { Sangamankandy }\end{array}$ & 1273 & 4 & 1265 & 6 & 2538 & 10 \\
\hline Palamunai & 586 & 2 & 597 & 3 & 1183 & 5 \\
\hline Oluvil & 1300 & 4 & 1401 & 7 & 2701 & 11 \\
\hline Total & $\underset{\mathrm{N}}{\mathbb{N}}$ & $\ddot{\infty}$ & $\underset{\Xi}{\exists}$ & 2 & $\underset{\text { N }}{\stackrel{N}{ٍ}}$ & $\bar{\Xi}$ \\
\hline
\end{tabular}

Secondary information was collected from the mineral mining project EIA report, which was a reconnaissance survey conducted to identify major social-economic profile and community assets around the study area.

\section{RESULTS}

Special focus on Coastal resource dependency: -

Generally, people along the coastal areas enjoy socioeconomic, ecological, and environmental-related benefits through coastal resources. Table 3.01 records the dependency on the coastal resources as $89.63 \%$.

Table 3.01 The degree of people depending on coastal resource from the villages of study areas 
The extent of Coastal resource dependency in the year 2020. The degree of coastal resource dependency investigated from the study areas in the year 2020, which is pointed out in figure 3.01 .

Fig 3.01: The extent of Coastal resource dependency in the year 2020 .

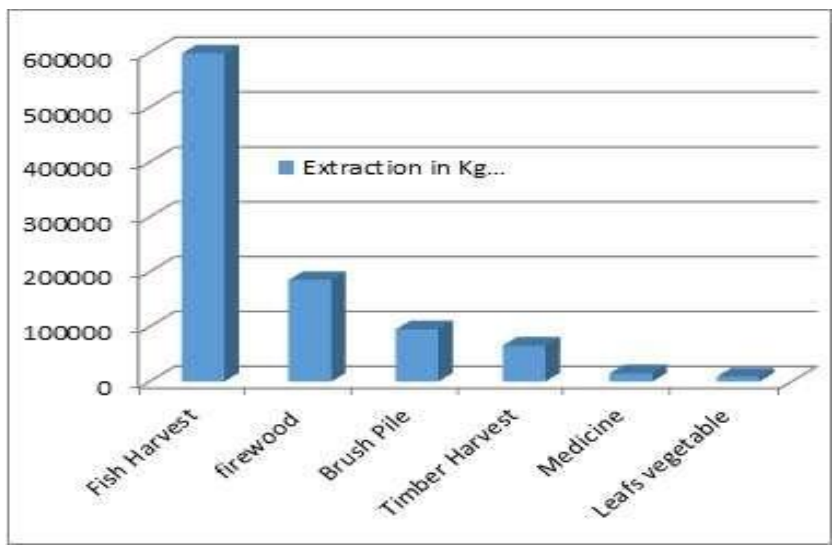

According to figure 3.01, fish harvesting is the most major dependency in the study area. The annual fish catch of the study area was 3,818,221 kg. Lagoon fishing is the major dependency of the study areas. The average fish caught by a fisherman from the marsh is $12.7 \mathrm{~kg}$ per day. The total number of fisherman is about 835 and it is raging from 6-8 months in which they engage in fishing each year. Most women collect firewood from the marsh. The number of families is depending on fuelwood, as the energy source is 650 . The mean weight of a head load is $3.3 \mathrm{~kg}$ per day. The annual firewood requirement for consumption in these four villages was about 769,994 Kg. The number of brush pile fishery here is 118 . The mean weight of the brush pile collected is $2.0 \mathrm{~kg}$ per day. The total extraction of brush piles is $84,368 \mathrm{~kg}$. The amount of timber, medicine, leaves of vegetable could not be calculated, due to the lack of data. So, the number of houses built during the last year is 26 . For each house, approximately 107 sq. feet of timber is needed. One square foot is about $18 \mathrm{~kg}$. The annual timber requirement for consumption in these four villages was about $64,800 \mathrm{Kg}$. The annual income is Rs 25,000.00 (approximately); of this income, Rs 10,000.00 was obtained from herbal medicines and Rs 15,000.00 was from leafy vegetation.

\section{Socio-economic profile of the study areas:}

The five selected villages; Komari, Thirrukovil, Tampaddai, Palamunai and Oluvil are located close to the selected project site, which is covered with natural resources.

\section{Population Characteristics and Population Distribution}

The study has been carried out covering eighteen GNDs under the four DSDs likely to be affected by heavy mineral sand mining.

Table 3.02. Population Distribution in the study area

\begin{tabular}{|c|r|r|}
\hline $\begin{array}{c}\text { Name of the } \\
\text { DSD }\end{array}$ & No. of Families & No. of Population \\
\hline Alayadiwembu & 79 & 240 \\
\hline Thirikkovil & 5,850 & 18,962 \\
\hline
\end{tabular}

\begin{tabular}{|c|c|c|c|c|}
\hline \multirow[b]{2}{*}{$\begin{array}{c}\text { Study } \\
\text { Villages }\end{array}$} & \multicolumn{2}{|c|}{ Dependency \% } & \multirow{2}{*}{ 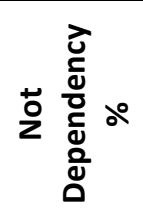 } & \multirow[b]{2}{*}{ Total } \\
\hline & $\begin{array}{l}\text { Full- } \\
\text { time } \\
\text { work }\end{array}$ & $\begin{array}{l}\text { Part- } \\
\text { time } \\
\text { work }\end{array}$ & & \\
\hline Komari & 15.23 & 3.85 & 3.57 & 22.65 \\
\hline Thirrukovil & 17.13 & 7.52 & 2.54 & 27.19 \\
\hline Thamppaddai & 11.11 & 6.57 & 1.94 & 19.62 \\
\hline Palamunai & 08.20 & 04.02 & 1.12 & 11.21 \\
\hline Oluvil & 10.0 & 06.0 & 1.20 & 19.33 \\
\hline Total & 61.67 & 27.96 & 10.37 & 100 \\
\hline Pottuvil & & 232 & & 919 \\
\hline Addalachenai & & 350 & & 1,575 \\
\hline Study Areas & & 6,511 & & 21,696 \\
\hline
\end{tabular}

Source - District secretary statistical report - 2019

There are 18 GNDs in 04 DSDs with 6,511 families and a population of 21696 in the study area. Comparatively, Thirikkovil DSDs is highly populated because this area is situated adjoining the main road and townships.

Gender Composition of the Population: Female population $(52 \%)$ is slightly higher than the male population (48\%) in the study areas. The age group representing the labour force (1960 ) is dominant with a percentage of $67 \%$ in the study areas. The child population represents only $17 \%$. The elderly population is around $16 \%$.

\section{Level of Education in the study area}

The level of education is one of the basic social parameters used in recognizing the overall social status of the people living in an area. Therefore, the level of education of all the residents in the study area was studied.

Fig 3.02:The level of education in the year 2020.

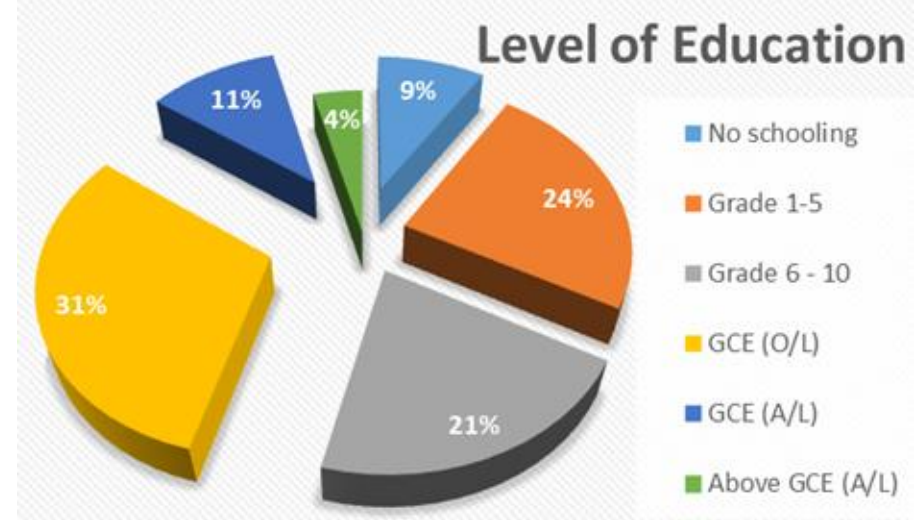

Figure: 3.02. above shows that the literacy level of the population is high. The majority has received at least secondary education $(46 \%)$. As much as $45 \%$ of the population has received primary education. The percentage of people who have never attended school or not in schooling age is only $09 \%$. The percentage of GCE (A/L) qualified students is around $16 \%$ and the number of graduates is very low.

\section{Income Generating Sources}


Two parameters were used in identifying existing incomegenerating activities in the study areas, namely, the occupation patterns, sources of income and monthly income pattern at the household level.

\section{Sources of Income}

Sources of income based on the household survey results are summarized in Figure 3.03 indicate that the majority of residents is depending on day to day unskilled labour activities and as a percentage, they represent nearly $33 \%$ of the population. These labour activities are mainly connected with the fisheries and agriculture in the area. The second major source of income in the area is fishing (22\%). This area is one of the main supply areas of fish and dry fish to the country. Meanwhile, agriculture is also a popular income generation sector (18\%) in the area but lack of water during the dry season and flooding of their paddy fields during the rainy season are the main problems faced by farmers in the study area. However, the farmers derive seasonal incomes in the Yala \& Maha season (cultivation seasons) of the year. Meanwhile, 13\% of dwellers depend on government or private sector jobs and receive fixed monthly salaries. In addition, over $15 \%$ of dwellers depend on Samruddhi and other social welfare assistance.

Figure 3.03: Sources of Income in the Project Area, analyzed at GND Level

\section{Family income source in Study area

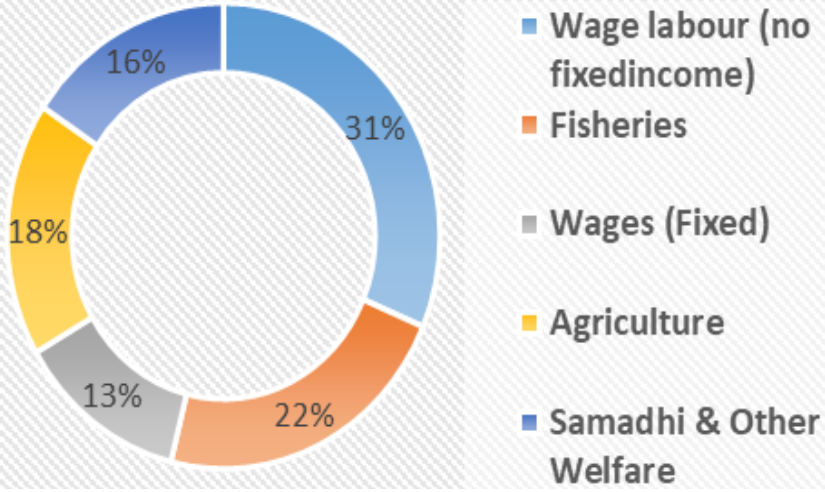

\section{Income Distribution Pattern}

Figure 3.04 shows that $80 \%$ of the households earn a monthly income of less than Rs. 15,000. It highlights the level of poverty in the area. The rest of them earn a monthly income of over Rs. 15,000.00. Meanwhile, $20 \%$ of the households represent the very poor group within the study area.

Figure 3.04 shows the income distribution among the households in the study area.

Nearly, $80 \%$ of households are living under the poverty line who are earning a monthly income of less than Rs. 15,000.

\section{Communication and Transportation:}

\section{Groups of income ranges in SLRs.}

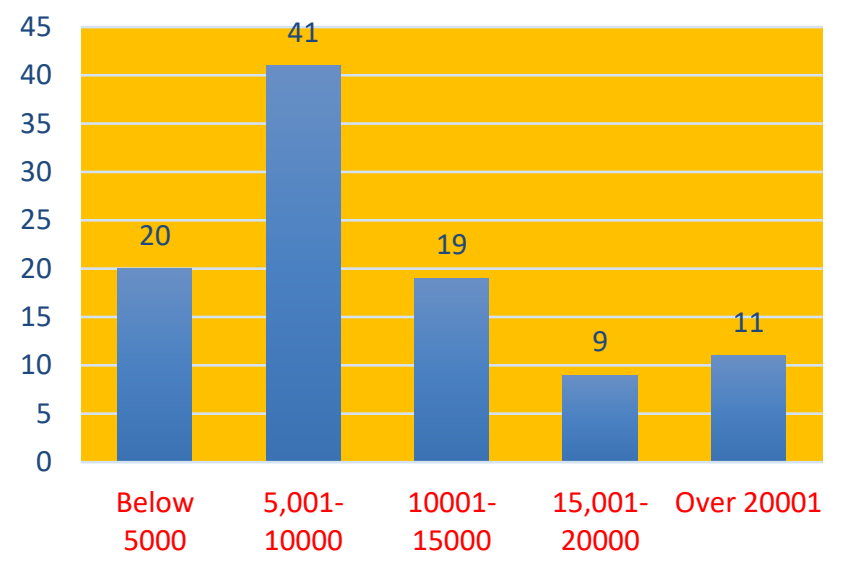

Many households use telephones as the main communication facility. The majority use mobile phones and few households have landlines. Five sub-post offices are situated within the study area and the main post offices are in Thirikkovil, Akkarapathu and Addalachenai townships. The main mode of transport from the study area (Thirikkovil) to Akkaraipattu, Pottuvil towns and other areas is the bus. Motor bicycles and push bicycles are also popular modes of transport in the area. In emergencies, the villagers use three-wheelers for their transportation.

\section{Road Network and Bridges}

One of the major roads called A4-Colombo-Batticaloa road runs through this study area. This road has been widened and carpeted recently, which has helped improve the linkages with the main towns, facilitating the people as they get easy access to markets for their fisheries and agricultural products. In addition, internal roads are gravelled and concreted.

\section{Domestic Water Facilities}

According to the field survey findings, the majority of the inhabitants still use protected and unprotected dug wells as water sources for their drinking and cooking purposes. Among those wells, a great majority is unprotected. The temporary shallow dug wells that enable people to tap groundwater at a depth of around $1.0 \mathrm{~m}$ are peculiar to this type of coastal areas. Meanwhile, the piped water supply facility provided by the National Water Supply and Drainage Board is limited to the inhabitants living along the main road. In addition, a few Tube Wells and Hand Pumps (TWHP) are in Thambilvil, Thirikkovil Vinayagapuram, Oluvil, Palamunai and Sangamankatha villages and villagers use them to get water for their domestic consumption.

\section{Sanitation Facilities}

According to the field survey, $73 \%$ of the households within the study areas have satisfactory sanitary latrines. Construction www.scirj.org

(C) 2021, Scientific Research Journal 
of pit latrines is impossible due to the high groundwater level in the area. Seepage pits for water-sealed latrines also have to be constructed taking the groundwater table into account. These difficulties have led the local authorities in the area to construct a few common latrine units adjoining the coastal belt for the use of people. Meanwhile, 20\% of the people are using temporary latrines ('latrines' are no latrines at all) but are merely places set aside for defecation. The remaining $6 \%$ of villagers do not have any type of latrine and they use the closest shrub jungle for defecation and $1 \%$ of fishermen are using beach area for this purpose.

\section{Power Supply (Electricity)}

The majority of the households use electricity for lighting and other purposes. But $12 \%$ of households do not have an electricity facility. Kerosene and firewood are commonly used as sources of domestic energy.

\section{Health Care}

The nearest rural hospital is in Thirikkovil at a distance of 2-3 kilometres and Palamunai at a distance of 1.5-2.5 kilometres from the proposed process plant in the study area. In addition to that, there are six private medical centres in Thirikkovil, Vinayagapuram, Sangamankandy, Oluvil, and Palamunai villages. The nearest general hospitals are situated in Akkaraipattu and Pottuvil townships.

\section{Community assets in the study areas}

A total of 48 community assets such as religious places, multipurpose community buildings, fishermen's restrooms and cemeteries are along the coastal belt within a $500 \mathrm{~m}$ radius of the study area. But, except for two Hindu temples, a cemetery and a church, all the other community assets are $100 \mathrm{~m}$ away from the beach zone within the study area.

Table 3.03: Community assets in the study areas

\begin{tabular}{|c|c|c|c|c|c|c|c|}
\hline Name of Villages & 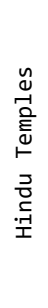 & $\begin{array}{l}n \\
\vdots \\
o \\
\tilde{y} \\
\end{array}$ & 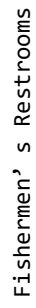 & 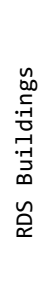 & 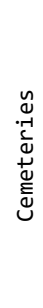 & 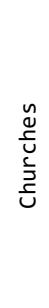 & 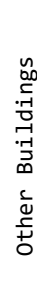 \\
\hline Sinnamuhathuaram & 1 & 0 & 1 & 0 & 1 & 4 & 2 \\
\hline Thambaddal & 4 & 0 & 3 & 3 & 3 & 0 & 1 \\
\hline Thirikkovil & 3 & 0 & 1 & 1 & 1 & 2 & 3 \\
\hline Vinayagapuram & 1 & 0 & 1 & 0 & 1 & 1 & 0 \\
\hline Sangamamgram & 2 & 0 & 2 & 4 & 1 & 0 & 0 \\
\hline Palamunai & 0 & 0 & 0 & 0 & 0 & 0 & 0 \\
\hline Oluvil & 0 & 1 & 0 & 0 & 0 & 0 & 0 \\
\hline
\end{tabular}

Total

\begin{tabular}{l|l|l|l|l|l|l|}
11 & 1 & 8 & 8 & 7 & 7 & 6 \\
\hline
\end{tabular}

According to Table 3.03, two Hindu temples in Sinnamuhathuaram and Thambaddal 01 GNDs, a church in Sinnamuhathuaram GND, a School in Oluvil and a cemetery in Thambaddal 01 GND are vulnerable and will get affected during the Project operation due to close vicinity (within $100 \mathrm{~m}$ distance from the sea). In addition, all fishermen's restrooms are located within a $100 \mathrm{~m}$ radius of the zone of the sea within the proposed project area. Therefore, those buildings are likely to face mining effects during the project operations.

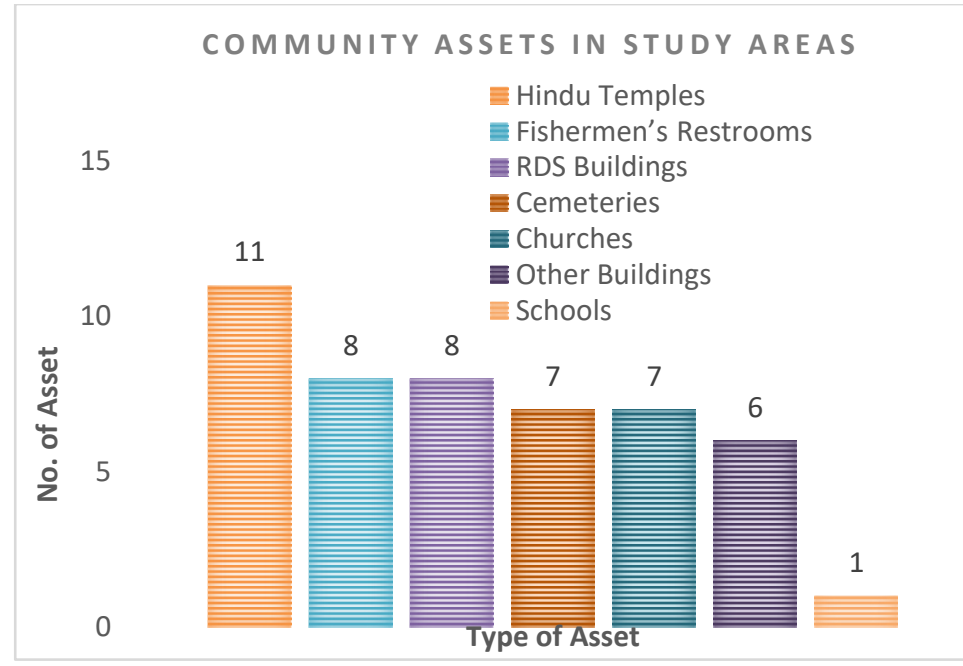

Most of these assets are connected to the fisheries industry and the lifestyle of fisherfolk.

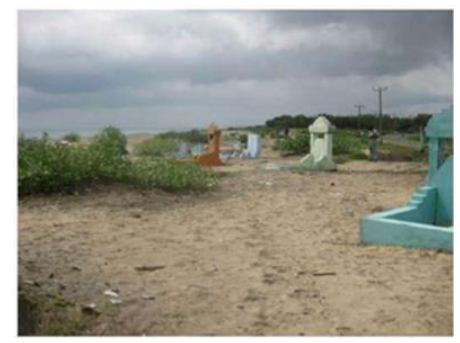

Photo 3.01: Cemetery

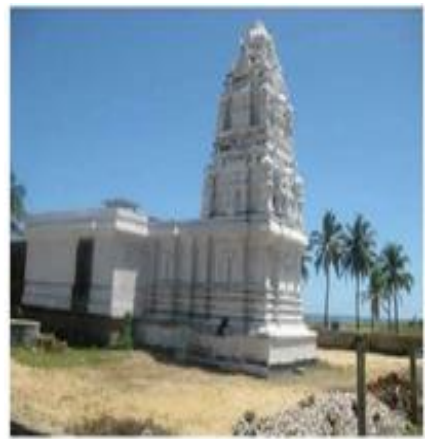

Photo 3.03: Hindu Temple

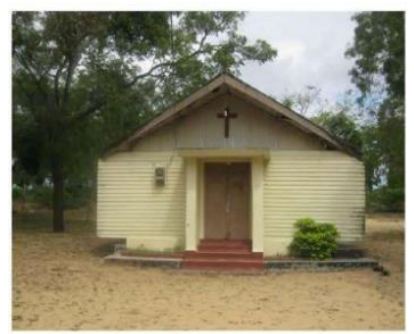

Photo 3.02: Churches

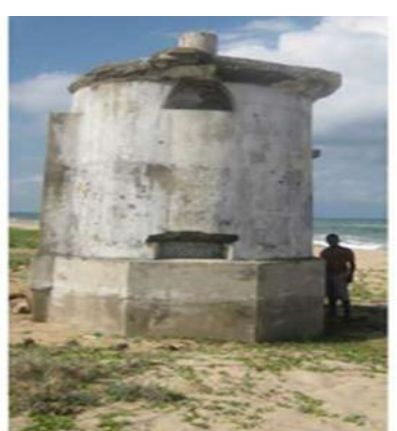

Photo 3.04: Lighthouse

\section{DISCUSSION}

Analysis of Causes and Effects on Social and Economic Conditions due to implementing the Project for Mining of 
Heavy Mineral Sands along the Akkaraipattu - Komari Coastal Stretch in the study area. According to the EIA report of the project, "Sangamankandy, Sinnamuthuharam and Thambaddal areas have less population within the proposed project area. However, no permanent human settlements are found in the proposed project area. Therefore, no disturbances to human settlements would occur". It cannot however be agreed to because, before Tsunami the population lived with more density very close to the beach, but after the tsunami particular people were resettled far away from their livelihood activities. According to my observation, many temporary structures are found in the project areas. According to the EIA report of the project; "The main processing plant will also be established within the Oluvil Port premises. This area is also located away from the human settlements. Therefore, no negative impacts could be expected on human settlements due to the new processing plant of the proposed project". According to my viewpoint, many houses, business centres, children's parks and government schools are found in the proposed main processing plant to be located in the Oluvil project site. Therefore, there would be possibilities for negative impacts by the heavy mining project to the public.

In addition, the internal roads are gravelled and concreted which help us to connect the proposed project area and the main road also exists. However, a majority of these relevant narrow byroads have inadequate and weak bridges which should be developed by the project proponent with the consultation of relevant local authorities in the area, to be used for transportation of mineral sand from the beach to the processing plant. According to the EIA report, "There are 25 schools situated in the study which cover the project area, but far away from the project area. In my field survey, it is recorded that there are 27 schools in the project area, but one is close to the mining mineral processing plant in the Oluvil area.

About $6 \%$ of the villagers do not have any type of latrine and they use the closest shrub jungle for defecation and $1 \%$ of the fishermen are using beach area for this purpose. According to the EIA Report, "However, no one uses the proposed project area for these purposes. Therefore, no negative impact can be expected on the existing sanitation situation in the area by the proposed project". But $1 \%$ of the fishermen are using beach area for defecation. According to the EIA Report, "However, proposed project activities may not negatively affect the existing domestic water consumption pattern in the area due to long distances". But, according to my observation, the structure of soil might change when salt water is used for cleaning and mineral separating during the mineral mining process.

A total of 48 community assets such as religious places, multipurpose community buildings, fishermen's restrooms and cemeteries are situated along the coastal belt within a $500 \mathrm{~m}$ radius of the proposed project area. But except for the two Hindu temples, a cemetery and a church, all the other community assets are $100 \mathrm{~m}$ away from the beach zone of the sea within the project area. According to the Project EIA report, the two Hindu temples in Sinnamuhathuaram and Thambaddal 01 GNDs, a church in Sinnamuhathuaram GND and a cemetery in Thambaddal 01GND are vulnerable and will get affected during the Project operation due to close vicinity (within $100 \mathrm{~m}$ distance from the sea). In addition, all fishermen's restrooms are located within a $100 \mathrm{~m}$ radius of the zone of the sea within the proposed project area. Therefore, those buildings are also likely to face mining effects during the project operations. Most of these assets are connected to the fisheries industry and the lifestyle of fisherfolk.

\section{CONCLUSION}

Analysis of Causes and Effects of Social and Economic Conditions in the study area:

- Nearly $85 \%$ of household is living under the poverty line;

- $80 \%$ of the household are earning a monthly income of less than Rs. 15,000;

- Internal roads are gravelled and concreted which help to connect the main road also in very bad condition;

- A majority of these relevant narrow byroads has inadequate, broken culverts and weak bridges which should be developed by the relevant local authorities in the area;

- Many temporary structures are found in the project areas;

- Many houses, business centres, children's parks and government schools are found in the proposed main processing plant located in the Oluvil project site;

- It has been recorded that there are 27 schools in the project area, but one is close to the mining mineral processing plant at Oluvil area;

- $1 \%$ of the fishermen are using beach area for defecation;

- while the minerals mining process may negatively affect the domestic water consumption pattern due to the structure of the soil. it is going to be changed if saltwater is going to be used for cleaning and minerals separating;

- Many buildings are likely to face mining effects during the project operations as most of these assets are connected to the fisheries industry and the lifestyle of fisherfolk; and

- The age group representing the labour force (19-60) is dominant with a percentage of $67 \%$ in the study area and they are unemployed and are looking for job opportunities.

Nature of households and Principal economic activities. As mentioned above, the proposed Project area shows typical coastal village features and the lifestyles of the people in the study area are patterned accordingly. A majority of residents within the proposed project area is dependent on day to day labour activities related to the existing fishing and farming industries.

The second majority of dwellers is fishermen and therefore their life pattern is quite simple. The majority of dwellers have no fixed monthly income. They depend on seasonal incomes by fisheries or agricultural activities. Inhabitants in the proposed project area represent Tamil-Hindu, Tamil-Catholic and Islamic ethnoreligious groups. A few Sinhalese and Buddhist families live in the Sangamnkandy area. 
It was very important to study the employment pattern in the area to identify their principal economic activities. Therefore, the researcher analysed the existing occupation pattern.

According to the project development plan, if any community assets or cultivations such as coconut plantations are situated within the project operation zone, it is planned to allocate a 100 $\mathrm{m}$ buffer zone from each establishment/plantation and the mining of mineral sand will not take place within this buffer zone.

How would it help to avoid unnecessary negative impacts on existing community assets within the proposed Project area.

The age group representing the labour force (19-60) is dominant with a percentage of $67 \%$ in the study area. The details indicate that the proposed project has the opportunity to find employees from the area itself. There is however no appropriate plan.

According to the development plan of the project, it would create around 195 employment opportunities for local people in the first year of the project operation period. It will increase annually and reach up to 266 in the fifth year of the project operation period.

How many residents (local people) can get employment opportunities from this project. These are the direct job opportunities and in addition, more indirect employment opportunities will also be created through related services such as transportation and commercial activities. There is a possibility to find unskilled labourers from the adjoining villages which will undoubtedly enhance their living standards. It is also realized that large numbers of villagers are unemployed in Oluvil - Akkaraipattu - Thitukkovil - Komari region in Ampara District mainly due to the lack of industries in the area. Therefore, it could be stated that more job opportunities will be created from this project for people living in the area and adjoining areas on a short and long term basis.

From Environment Impact Assessment Report, it is learned the proposed project on mining of heavy mineral sands along the
Akkaraipattu-Komari coastal stretch and establishment of mineral processing factory at Oluvil Port premises was planned to ensure that the proposed development project is environmentally sustainable, economically viable and socially acceptable and also to identify potential environmental impacts at the early stages of the project.

\section{REFERENCES}

[1] Dangalla. N.D.K, "Report of the Socio-Economic Survey of Negombo Lagoon", Pages - 5-7, 12, 21, 33-37.

[2] Amarasingha. M.D, Liyanagey.S, "Contribution of Mangrove Resources to the Socio-Economic Status of Adjacent Human Communities along the Western Southern Coasts of Sri Lanka", 1996, IUCN- Forest Department of Sri Lanka.

[3] Pinto. L, "Mangrove of Sri Lanka, Natural Resources, Energy and Science Authority of Sri Lanka", 1986, Pages - 2-6,24,26,32.

[4] Amarasingha. M.D, Socio-Economic Status of the Communities of Selected Mangrove Areas on the West Coast of Sri Lanka, Mangrove Eco-System Occasional, Paper No-03, 3-7.

[5] Herath, M.M.J.W., "Economic Geology of Sri Lanka, Ministry of Industrial Development Publication," 1995.

[6] G. Eason, B. Noble, and I. N. Sneddon, "Coastal Resource Profile for Ampara District,”. Final Report, January 2010, Pp160.

[7] NECCDEP, "An Analysis of the Past, Present and Potential Impact on Rural and Urban Development on Coastal Resources in the Eastern Province", August 2010, Final Report, Pp71.

[8] NECCDEP, An Analysis of Current and Future Economic Value of Coastal Resources in the Eastern Province in Sri Lanka,". January 2010, Final Report, Pp166,

[9] Anon, "A Manual and Strategy for Conservation and Development of Wet Lands of Sri Lanka, Wet Lands are No Waste Land, Wetland Conservation Project, Sri Lanka, CEA, Euro Consult, 12,44, 47, 51.

[10] Anon, 2000. Conservation Management Plan, Muthurajawela Mash and Negombo I CEA, Sri Lanka, Euro Consult, 20-29, 6870, 96-99, 121.

[11] Anon, 1993, Management of Mangrove Ecosystem in Sri Lanka, IUCN, Sri Lanka, 13, 15, 24. 